\title{
Deep insight on the behaviour of short fibres within a composite under uniaxial tensile \\ DOI: 10.35530/IT.072.06.1850
}

\section{ABSTRACT - REZUMAT \\ Deep insight on the behaviour of short fibres within a composite under uniaxial tensile}

This work presents an investigation of the mechanical properties of a composite structure manufactured from polypropylene matrix reinforced with jute waste fibres collected from textile industry with extrusion followed by injection techniques. Mechanical tests under uniaxial strain shows that this lightweight vegetal fibre significantly enhanced the mechanical performances of the whole composite with a very slight quantity of compatibilizer which positively influences the final price of the composite. The fracture surfaces showed highly tethered as well as weakly anchored fibres to the matrix. Moreover, in order to have a deep insight on that anchoring behaviour, uniaxial tensile deformation was applied under Scanning Electron Microscopy and evidenced how the fibre/matrix interface plays a high role to strengthen the whole structure. The fibre and matrix interface is not simply resumed to high or weak anchoring but there is a combination of sticking and slipping of reinforcement on the polymeric walls.

Keywords: composites, natural fibre, mechanical performances, fibre/matrix interface

\section{Perspectivă aprofundată asupra comportamentului fibrelor scurte într-un compozit sub tracțiune uniaxială}

Această lucrare prezintă o analiză a proprietăților mecanice ale unei structuri compozite fabricate din matrice de polipropilenă armată cu fibre reziduale de iută colectate din industria textilă, realizată prin extrudare urmată de tehnici de injecție. Testele mecanice sub tracțiune uniaxială arată că această fibră vegetală ușoară îmbunătățește semnificativ performanțele mecanice ale întregului compozit, cu o cantitate foarte mică de compatibilizator care influențează pozitiv prețul final al compozitului. Suprafețele de fractură au prezentat fibre foarte legate, precum și slab ancorate în matrice. Mai mult, pentru a avea o perspectivă detaliată asupra acestui comportament de ancorare, deformarea la tracțiune uniaxială a fost aplicată la microscopia electronică cu scanare și a evidențiat modul în care interfața fibră/matrice joacă un rol important în consolidarea întregii structuri. Interfața fibră și matrice nu este pur și simplu reluată la o ancorare ridicată sau slabă, ci există o combinație de lipire și alunecare a armăturii pe pereții polimerici.

Cuvinte-cheie: compozite, fibră naturală, performanțe mecanice, interfață fibră/matrice

\section{INTRODUCTION}

In recent years, regarding some ecological, technical as well as economic reasons, the integration of natural cellulosic fibres within thermoplastic matrix as reinforcements of composite structures has drastically increased [1, 2]. Compared to high performance fibrous structures like carbon and glass fibres, natural cellulosic ones present no health risks for manufacture employees or end users. Markets associated to these composites are touching a wide range of applications in many industrial fields like transport and buildings. Automotive application is a field that uses many technical textile fibres as reinforcement for polymer composite, in particular, composite based on nonwoven materials made with short fibres. Recently, extensive research has been carried out on the application of natural fibres as reinforcement in a polymer composite [3], thanks to their availability, renewability, low density and low cost. Composites with thermoplastic resins are industrially preferred to thermosets as they enable lower processing costs due to low production cycle. Several natural fibres have been used as reinforcement of composites with thermoplastic polymer matrix [4], and those studies investigated the mechanical and thermal performances such impact strength, elastic modulus, thermal resistance... It has been shown that the key factor to reach high performances composites is the compatibility between matrix and fillers. The natural affinity between these components avoids chemical compatibilization and leads to low-cost materials.

In this paper, we use raw and chemically treated jute fibres as reinforcement. The valorisation by recycling of this industrial waste issued from spinning and weaving local industries to produce eco-friendly industrial products is an important economic and ecological challenge [5]. Many works have been conducted to explore the benefits of natural cellulosic fibres in a variety of applications like renewable dyes filters [6], production of cellulosic derivatives [7] or as matrix reinforcement [8]. This latter application is the object of this work, where the main focus is not only the mechanical performances of the composite, but we will mainly focus on the behaviour of the fibre/matrix interface under uniaxial tensile. For that reason, apart from the mechanical performances of 
the samples tested by classic dynamometry, a tensile device has been integrated within the Scanning Electron Microscope to pursue how fibres behave when a breaking tensile deformation is applied to the composite structure.

\section{MATERIALS AND METHODS}

\section{Fibres' extraction and composites preparation}

Fibres have been collected from wastes issued from spinning and weaving industries of jute fibres. They were placed on a horizontal opener. They are driven by a rolling lurking and then they are engaged in a threshing cylinder. Subsequently, they are driven by means of a toothed roller in order to separate fibres. By centrifugal force and aspiration, fibres are driven upwardly and the waste falls down. The fibre obtained after this mechanical treatment will be considered as raw fibres. The treated fibres were submitted to alkaline treatment involving the use of $20 \mathrm{~g} / \mathrm{l}$ of sodium hydroxide and $10 \mathrm{~g} / \mathrm{l}$ of sodium hypochlorite in mixture with a $1 / 100$ fibre/bath ratio. This system is maintained at $100^{\circ} \mathrm{C}$ for $60 \mathrm{~min}$. The treated fibres are then rinsed with hot water and dried in an oven at $105^{\circ} \mathrm{C}$ for $20 \mathrm{~min}$. This chemical treatment strengthens the fibres by eliminating some non-cellulosic components and removes impurities from fibre surface which improves the fibre/matrix interface [9, 10]. The composite material was prepared using an internal mixer (Haake Rheomix 600), coupled to a Polylab Rheocord 300p data acquisition system. This device allows mixing of rather small volumes of materials of $69 \mathrm{~cm}^{3}$ but it was filled to $70 \%$ of its capacity to ensure high compounding. The preparation follows three steps: at first, the polymer pellets are introduced in the mixer chamber heated to $180^{\circ} \mathrm{C}$ with contra rotative rollers turning at $100 \mathrm{rpm}$. This step remains $2 \mathrm{~min}$ to ensure the matrix melting. Then, in the second step which lasts 6 min, equal bursts of fibre are progressively introduced to the chamber every 2 min and that was found to allow an optimized compounding of fibres and matrix. When all the quantity of fibres is introduced into the chamber, the mixing lasts 2 minutes before stopping the rollers and extracting the composite. This latter will then be transformed into pellets using Reitsh grinding device equipped with a grid of $5 \mathrm{~mm}$ in diameter. Finally, pellets are injected at $180^{\circ} \mathrm{C}$ a Haake Mini Jet II press to obtain dog bone samples according to ISO 527-2 standard. The matrices of our study were polypropylene (PP) and polypropylene mixed (PPm) with anhydride maleic grafted polypropylene (AMgPP).

$\mathrm{PP}$ and AMgPP were, respectively, supplied by Total Petrochemicals and Arkema and commercialized under the nominations PPH 5060 and Orevac CA-100. The densities of fibres and polymers were measured using a pycnometer AccuPyc II furnished by Micromeritics. Measured densities are $1.5369 \mathrm{~g} / \mathrm{cm}^{3}$ for raw jute fibres, $1.4666 \mathrm{~g} / \mathrm{cm}^{3}$ for treated fibres, and $0.8845 \mathrm{~g} / \mathrm{cm}^{3}$ for the matrix.

\section{Mechanical analysis of composites}

The tensile test of the specimen were determined using universal testing machine (Instron), according to ISO 527 , with a traveling speed of $0,8 \mathrm{~mm} / \mathrm{min}$ and a cell of $30 \mathrm{kN}$. The distance between clamps for traction is fixed to $60 \mathrm{~mm}$.

\section{Scanning Electron Microscopy (SEM)}

Surface topography of raw and treated fibres as well as fracture surfaces of the composite structures were observed with a Quanta 200 FEG (FEI Company) in environmental mode at an acceleration voltage of $3 \mathrm{keV}$ and a pressure of around 0.7 Torr. The fibre and fracture surfaces were coated with carbon to avoid any degradation during observation. The SEM was equipped with an in situ tensile apparatus (DEBEN micro test, maximum load $5 \mathrm{kN}$ ) and direct observations of the crack propagation were done at a displacement speed of $0.1 \mathrm{~mm} / \mathrm{min}$ on notched specimens. Experiments were conducted on three samples per blend.

\section{RESULTS AND DISCUSSIONS}

\section{Morphological properties of the jute fibres}

Raw and treated jute fibres are presented in figure 1. The morphology of that fibre is presented as a beam of continuous elementary fibres joined together with lignin and pectin. When fibres are chemically treated, the fibres surface seems to be cleaner, and the stripes between the elementary fibres become more distinguishable. This cleaning contributes to a better affinity between the matrix and the reinforcement.

\section{Effect of fibre ratio and fibre/matrix compatibilization on the mechanical performances of composites}

The experiments associated to the effect of both fibre ratio and fibre treatment on the mechanical properties are summarized on the table below. We did not split the results as usually done because these effects are generally well known and extensively treated in the literature, whereas the main purpose of our work is to show the internal morphology of the composite structure when submitted to tensile strength.

First of all, the incorporation of fibres into the matrix increases the elastic modulus of about $49 \%$ for the less rigid combination associated to $10 \%$ of raw fibres fraction. It could reach $140 \%$ for $20 \%$ of chemically treated short jute fibres. The increase of fibres ratio increases the mechanical performances of the composite structure. This is essentially due to the increase of the contact area between matrix and reinforcement that help to transfer the stress from one component to the other toward their interface. This result evidenced the importance of the compatibilization between the fibres and the matrix leading to stronger adhesion and better stress transfer leading to better resistance to uniaxial tensile stress in the elastic region and also before total break [12-15]. This deduction is confirmed as we apply a chemical 


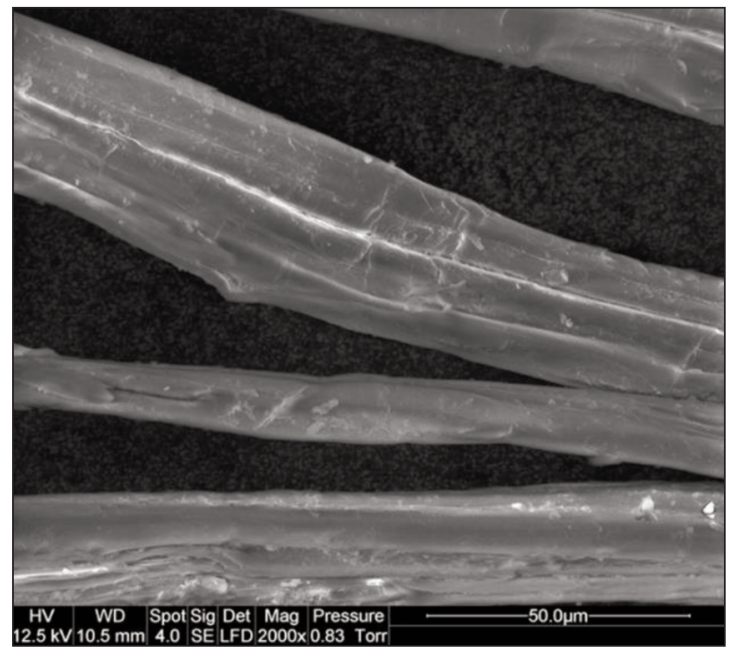

a

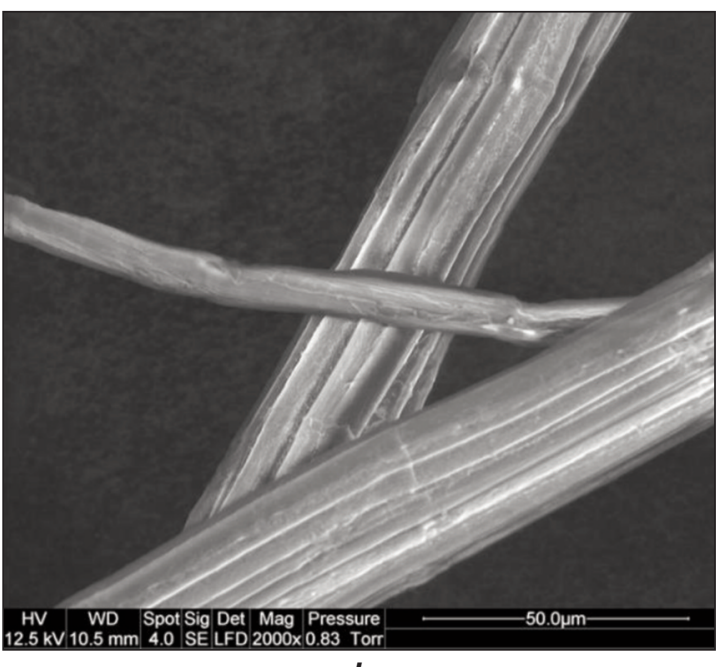

b

Fig. 1. SEM micrographs of jute fibres: $a$ - in raw state; $b$ - treated chemically

treatment to the reinforcement. In fact, the alkali treatment applied to the fibres increases the elastic modulus by around $17 \%$ for both fibres ratios. The break resistance is improved as well. The compatibilization is responsible of the fibre/matrix adhesion improvement which also leads to a better dispersion of the fibres within the matrix $[5,11]$. The failure surfaces associated to the raw fibres have been focused on with SEM presented on figure 2 and show the existence of voids or protruding fibres for raw reinforcement. We could also notice some fibres footprint on the matrix. These phenomena are explained by the fact that fibres have been exfoliated from the matrix without breakage. So, the interface did not play a strong role to maintain the compactness of the whole structure. In the other side, better adhesion between the fibres and the matrix could be seen when fibres are chemically treated. It generates a better coating of the fibres with the matrix presented on figure 3. This high bonding energy leads to a breakage of the fibres and we morphologically observe broken fibres and not highly protruding from the matrix.
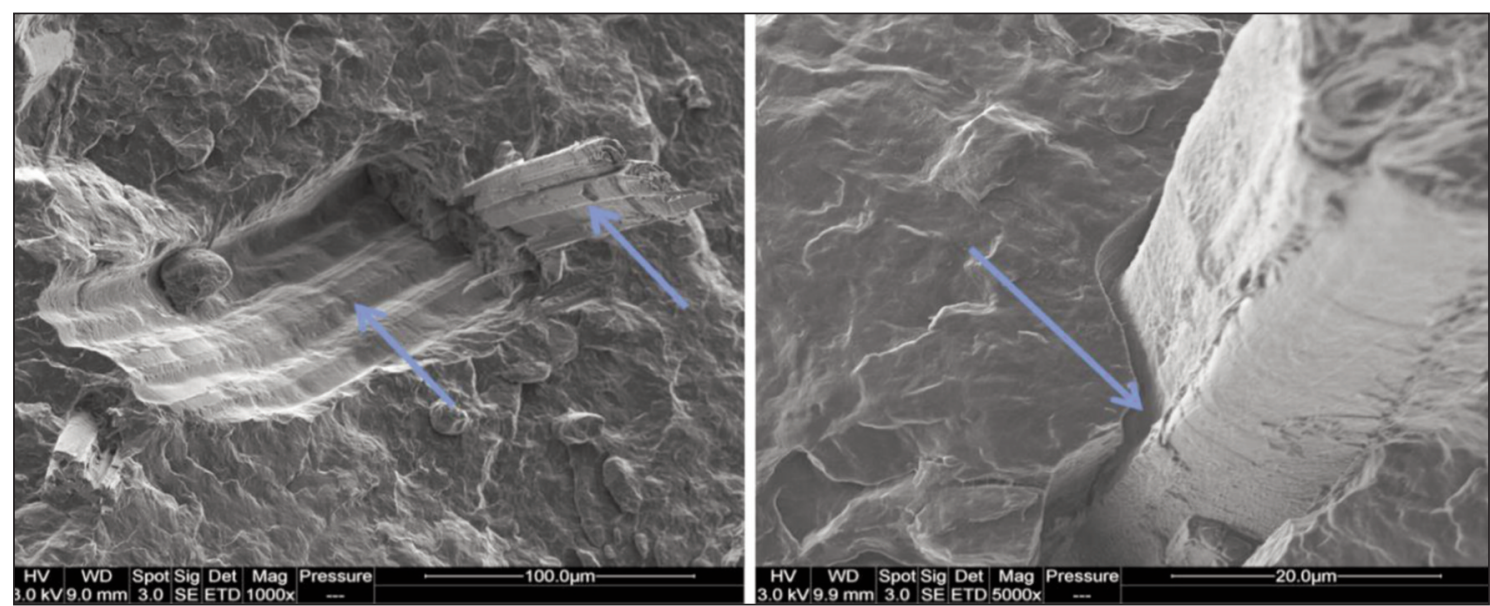

Fig. 2. Fracture surface of composite reinforced with raw fibres, effects of weak tethering of the fibre

Fig. 2. Fracture surface of composite reinforced with raw fibres, effect
to the matrix indicated with arrows
Table 1

\begin{tabular}{|c|c|c|c|}
\hline \multicolumn{4}{|c|}{$\begin{array}{c}\text { MECHANICAL PERFORMANCES OF COMPOSITE } \\
\text { MATERIALS FOR VARIOUS TREATMENTS } \\
\text { AND FIBRE RATIOS }\end{array}$} \\
\hline Specimen & $\begin{array}{c}\text { Fibre } \\
\text { weight ratio } \\
(\%)\end{array}$ & $\begin{array}{c}\text { Young } \\
\text { Modulus E } \\
\text { (MPa) }\end{array}$ & $\begin{array}{c}\text { Stress } \sigma \\
\text { (MPa) }\end{array}$ \\
\hline $\begin{array}{c}\text { Matrix } \\
\text { PP/PPgMA }\end{array}$ & 0 & $1230 \pm 75$ & $19 \pm 1.2$ \\
\hline Matrix/raw jute & 10 & $1837 \pm 90$ & $26 \pm 1.5$ \\
\hline Matrix/raw jute & 20 & $2714 \pm 166$ & $29.1 \pm 1.75$ \\
\hline $\begin{array}{c}\text { Matrix/treated } \\
\text { jute }\end{array}$ & 10 & $2150 \pm 154$ & $28.2 \pm 0.75$ \\
\hline $\begin{array}{c}\text { Matrix/treated } \\
\text { jute }\end{array}$ & 20 & $3159 \pm 211$ & $34.5 \pm 2.5$ \\
\hline
\end{tabular}

Nevertheless, these conclusions are based only on the final state of the broken samples. They are most likely deductions from final states observed on SEM. In fact, the breakage of fibres could succeed a slight slippage inside the structure and a protruding fibre could occur after breakage of this reinforcement in 

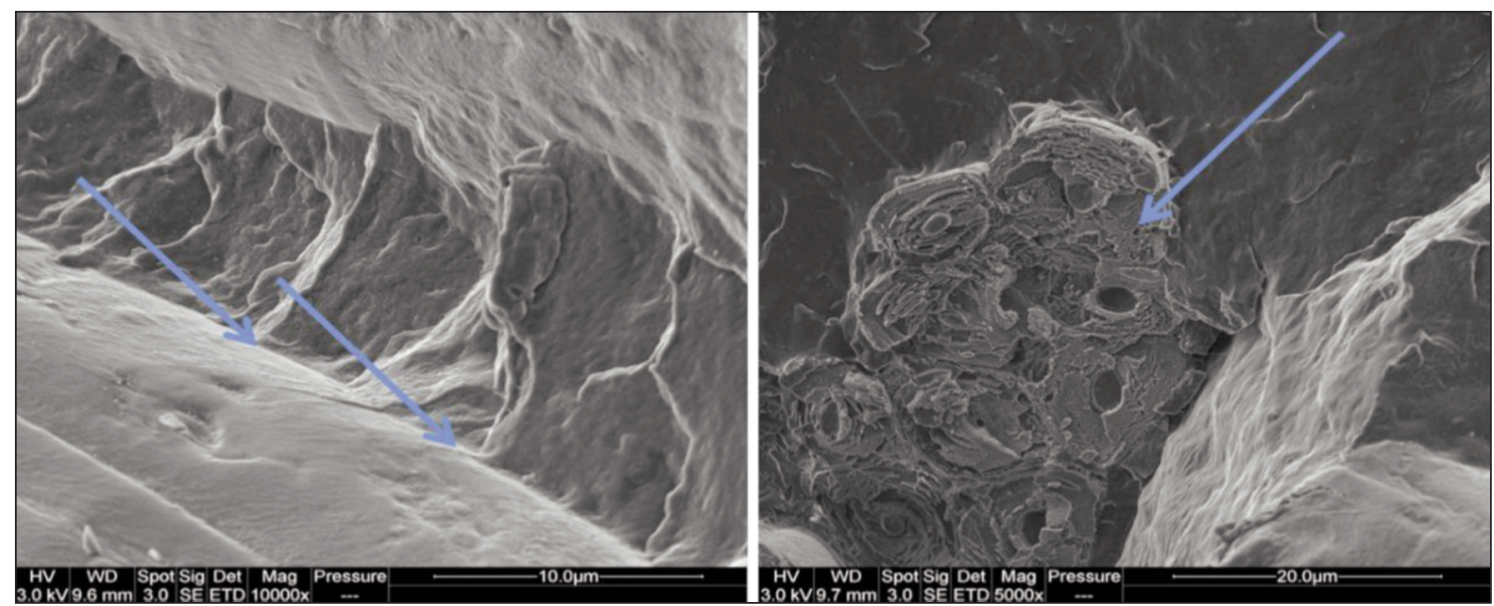

Fig. 3. Fracture surface of composite reinforced with treated fibres, effects of improvement tethering of the fibre to the matrix indicated with arrows

the internal part of the matrix. In that case, we are facing a problem of a partial efficient adhesion which may be associated to non-homogeneous chemical treatment of the fibres. To have a deeper insight on what happens within the structure; it becomes necessary to have highly amplified SEM micrographs in situ to pursue the fibres behaviour during uniaxial deformation until breakage.

\section{Fibre behaviour under tensile strain inside the composite structure}

This study is based on morphological observations under SEM. The composite surface has been finely eroded mechanically until fibres become clearly apparent. That action does not affect the fibre matrix contact. This operation helps to detect the movement of the fibre clearly by the microscope. A slight notch was applied on one lateral side of the material to ensure that failure will take place around the notched region and focus the microscope there. The samples have been submitted to uniaxial strain at a velocity of $0.1 \mathrm{~mm} / \mathrm{min}$ until failure. Elongation and force associ-

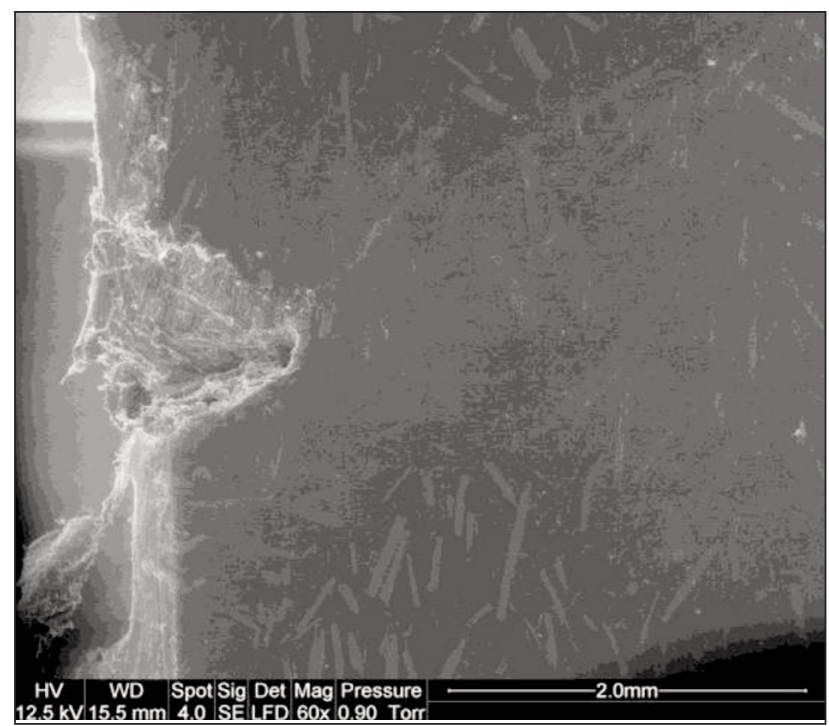

Fig. 4. SEM micrographs associated to eroded composite surface showing raw fibres distributions and notched region ated to each specific micrographs are indicated on high corner in millimetre and in Newton, respectively. Figure 4 shows the notch and the distribution of fibres on eroded surface eroded composite. It evidenced an isotropic distribution of fibres within the resin. When submitted to uniaxial strain, fibres could be split into three main groups, those oriented in the direction of the strain, those perpendiculars and those with oblique orientation.

We focus on the fibres around the notch to detect their behaviour under uniaxial mechanical traction as the notch is considered as the weakness zone where fracture must occur. Figures 5 and 6 present the behaviour of raw fibres inside the composite submitted to uniaxial strain, these fibres have orientations belonging to the three groups cited above. Applied strain is indicated on each microscopic shot. Wide images present the localization of the pursued fibres within the structure, and then we focus on the behaviour of this zone by enlarging it to detect details.

For fibres almost oriented in the direction of strain, we observe on figure 5 two phenomena; the first one is indicated with circles and consists on a detachment of the fibre from the matrix then slippage, inducing a void on the fracture surface or a protruding fibre in the second fracture surface. The second phenomenon is the breakage of the fibre then its detachment as indicated with rectangle. That fact means that tethering between fibres and matrix exists but presents some weakness points.

When fibres are lying toward the structure, the interface is much more solicited and it brakes rapidly as shown by different arrows types on figure 6 . At that stage, physical affinity does not have any efficiency to transfer the stress and a strong chemical tethering is needed to reinforce the whole material.

When chemical treatment is applied to the fibre, chemical bonds take place leading to more compaction of the whole structure. This affects the mechanical performances of the composite (elasticity and/or fracture stress) and is generally attributed to better stress transfer between fibres and matrix. 


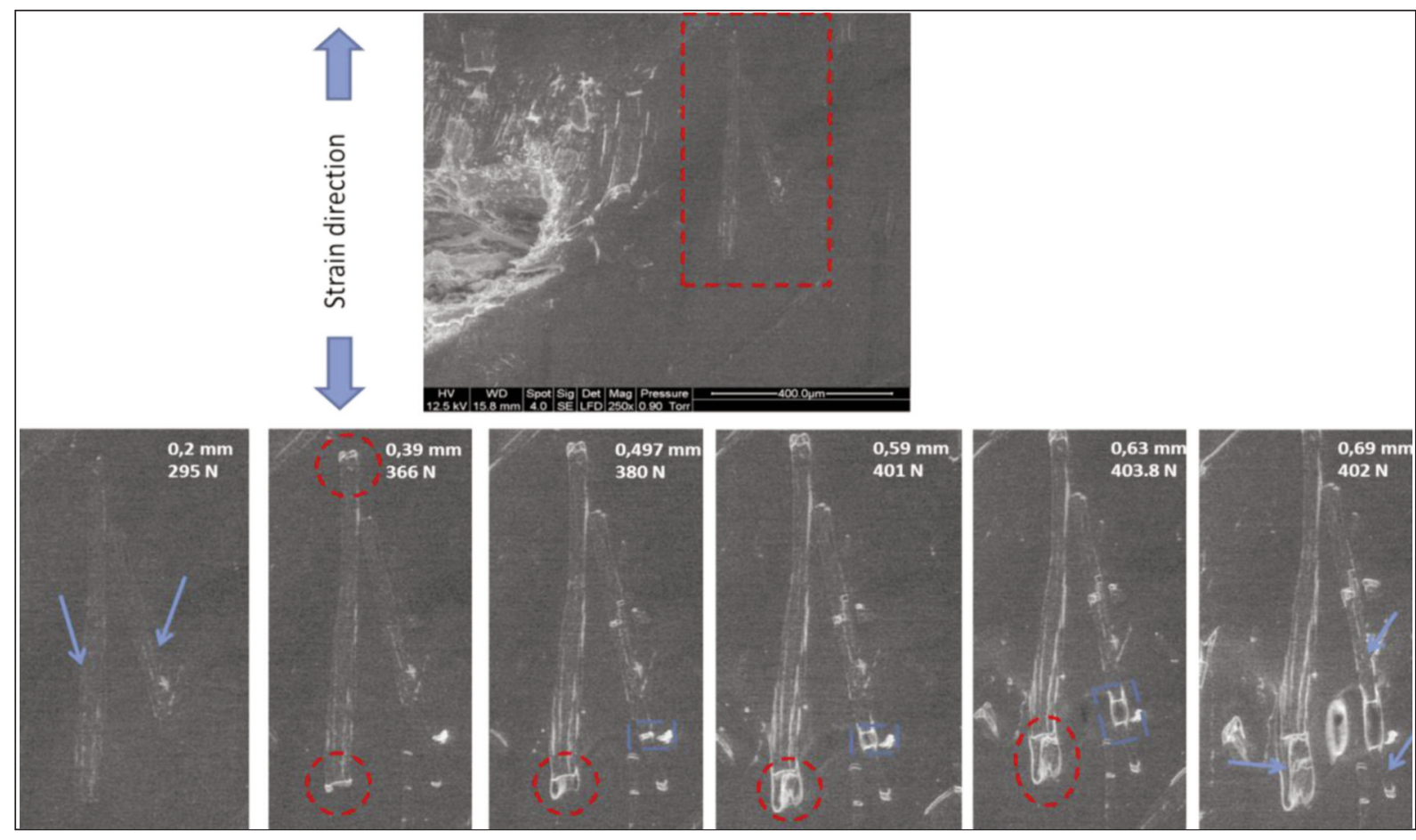

Fig. 5. SEM micrographs associated to raw fibres and matrix interfaces when submitted to uniaxial strain, fibres are mostly oriented in the direction of strain

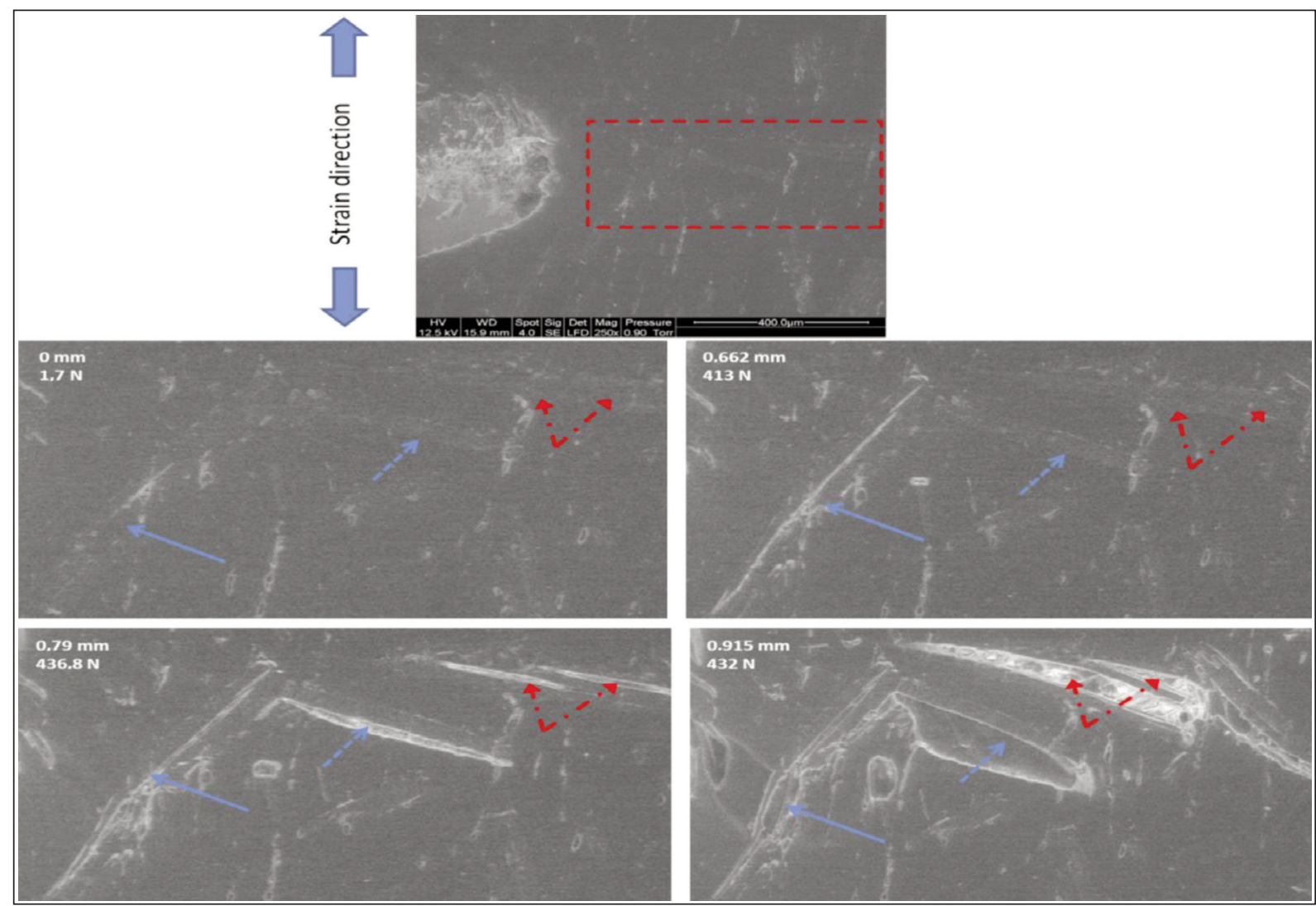

Fig. 6. SEM micrographs associated to fibres and matrix interfaces when submitted to uniaxial strain, arrows indicate interface detachment

Figure 7 confirms these hypotheses. It shows the behaviour of the fibres treated chemically inside the matrix submitted to strain. It evidences fibres failures more than detachment and slippage outside the structure.
That will be depicted on fracture surfaces by much more broken reinforcements than voids. Of course, voids will always exist but less in number as far as the chemical bonds between fibres and matrix are strong. 


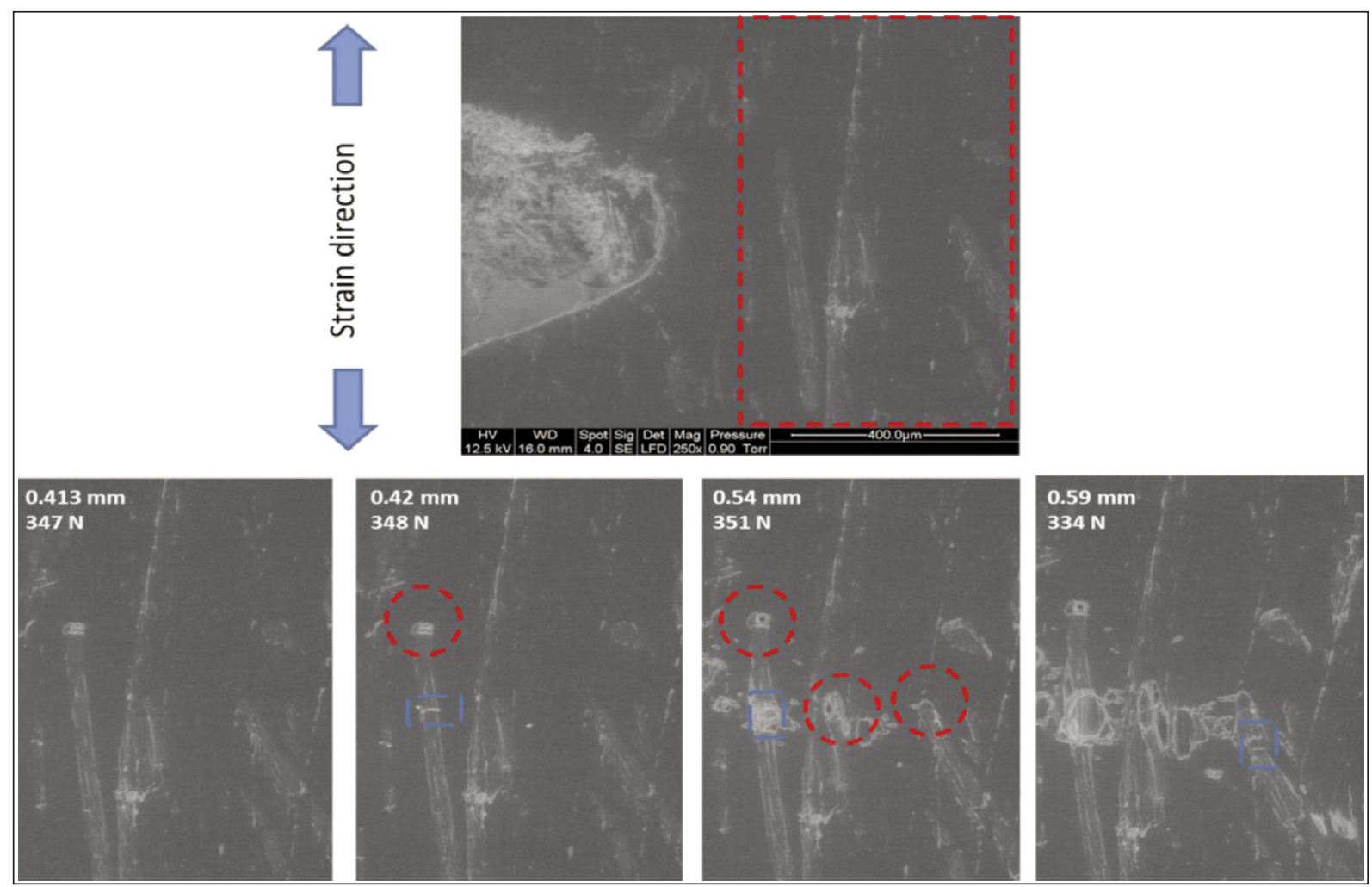

Fig. 7. SEM micrographs associated to treated fibres and matrix interfaces when submitted to uniaxial strain, detachment is indicated with red circles and fibre break with blue rectangle

\section{CONCLUSIONS}

This paper investigated the mechanical properties of composite material reinforced with raw and chemically treated jute fibres. Composites showed usual encountered tendencies for mechanical performances which are enhanced with fibre ratio increase and the addition of compatibilization treatments. We focused on the fibre/matrix interface when the composites are submitted to uniaxial strain by pursuing the fractured region under SEM. It has been shown that fibres have isotropic orientation inside the matrix. For low bonding strength, vertical and oblique oriented fibres are detached from the matrix but could be also fractured than untethered from the resin by slippage. That observation evidenced a non-homoge- neous contact between fibres and matrix. Fibres which are mostly oriented perpendicularly to the strain direction are detached from one side of the fractured sample leading to fibre footprint on the fracture surface. When the fibre/matrix interface is improved with chemical treatment, fibres stick stronger to matrix leading to their fracture. Some fibres break inside the matrix then are detached and some voids are observed on fracture surface. The interpretations associated to such voids could not be confirmed using common deductions which stipulate the detachment of the whole fibre, but we must have deep insight on that behaviour, for example by using the method proposed in this research work.

\section{REFERENCES}

[1] Graupner, N., Herrmann, A.S., Müssig, J., Natural and man-made cellulose fibrereinforced poly(lactic Acid) (PLA) composites: an overview about mechanical characteristics and application areas, In: Composites Part A: Applied Science and Manufacturing, 2009, 40, 810-821

[2] Zannen, S., Zouari, R., Hassen, M.B., Jeanmichel, R., Molina, S., Design of high mechanical and thermal resistant composites using marine plant waste, In: Industria Textila, 2018, 69, 6, 446-450, http://doi.org/10.35530/ IT.069.06.1515

[3] Dicker, M.P.M., Duckworth, P.F., Backer, B.F., François, G., Hazard, M.K., Weaver, P.M., Green composites, a review of material attributes and complementary applications, In: Composites part A: applied science and manufacturing, 2014, 56, 280-289

[4] Deepak, V., Siddharth, J., Effect of Natural Fibers Surface Treatment and their Reinforcement in Thermo-Plastic Polymer Composites: A Review, In: Current Organic Synthesis, 2017, 14, 186-199

[5] Dural, M.U., Cavas, L., Papageorgiou, S.K., Katsaros, F.K., Methylene blue absorption on activated carbon prepared from Posidonia oceanica (L.) dead leaves: kinetics and equilibrium studies, In: Chemical Engineering Journal, 2011, 168, 77-85

[6] Ncibi, M.C., B. Mahjoub, M. Seffen, Investigation of the sorption mechanisms of metal-complexed dye onto Posidonia oceanica (L.) fibres through kinetic modelling analysis, In: Bioresource Technology, 2008, 99, 5582-5589 
[7] Aguir, C., Mhenni, M.F., Experimental study on carboxymethylation of cellulose extracted from Posidonia oceanic, In: Journal of Applied Polymer Science, 2006, 98, 1808-1816

[8] Ragoubi, M. , Zouari, R., Ben Abdeljawad, M., Terrié, C., Baffoun, A., Alix, S., Leblanc, N.; Design of doum palm fibers biocomposites by Reactor/elongational flow MiXer: Evaluation of morphological, mechanical, and microstructural performances, In: Polymer composites, 2018, 39, 51, 519-530

[9] Sawpan, M.A., Pickering, K.L., Fernyhough, A., Effect of Fibre Treatments on interfacial Shear Strength of Hemp Fibre Reinforced Polylactide and Unsaturated Polyester Composites, In: Composites Part A: Applied Science and Manufacturing, 2011, 42, 1189-1196

[10] Alsaeed, T., Yousif, B.F., Ku, H., The potential of using date palm fibres as reinforcement for polymeric composites, In: Materials and design, 2013, 43, 177

[11] Zouari, R, Domenech, T., Vergnes, B., Peuvrel-Disdier, E., Time evolution of the structure of organoclay/polypropylene nanocomposites and application of the time/temperature superposition principle, In: Journal of Rheology, 2012, July/August, 56, 4, 725-742

[12] Ragoubi, M., Bienaimé, D., Molina, S., George, B., Merlin, A., Impact of corona treated hemp fibres onto mechanical properties of polypropylene composites made thereof, In: Industrial Crops Prod., 2010, 31, 2, 344-349

[13] Prasad, L., Kumain, A., Patel, R.V., Yadav, A., Winczek, J., Physical and Mechanical Behavior of Hemp and Nettle Fiber-Reinforced Polyester Resin-based Hybrid Composites, In: Journal of Natural Fibers, 2020, 1-16, http://doi.org/10.1080/15440478.2020.1821284.

[14] Premnath, A.A., Impact of surface treatment on the mechanical properties of sisal and jute reinforced with epoxy resin natural fiber hybrid composites, In: Journal of Natural Fibers, 2019, 16, 5, 718-728

[15] Khalid, M.Y., Imran, R., Arif, Z.U., Akram, N., Arshad, H., Al Rashid, A., García Márquez, F.P., Developments in Chemical Treatments, Manufacturing Techniques and Potential Applications of Natural-Fibers-Based Biodegradable Composites, In: Coatings, 2021, 11, 3, 293

\section{Authors:}

\section{RIADH ZOUARI ${ }^{1}$, EMILIA VISILEANU ${ }^{2}$}

${ }^{1}$ Textile Engineering Laboratory - LGTex, University of Monastir, Av Haj Ali Soua, BP68, 5070 Ksar Hellal, Tunisia

${ }^{2}$ National Research Development Institute for Textiles and Leather,

16, Lucretiu Patrascanu Street, Bucharest, Romania e-mail: e.visileanu@incdtp.ro

\section{Corresponding author:}

RIADH ZOUARI

e-mail: Riadh.Zouari@ksarhelal.r-iset.tn 